\title{
Diversity of the piRNA pathway for nonself silencing: worm-specific piRNA biogenesis factors
}

\author{
Natsuko Izumi and Yukihide Tomari ${ }^{1}$ \\ Institute of Molecular and Cellular Biosciences, The University of Tokyo, Bunkyo-ku, Tokyo 113-0032, Japan
}

The PIWI-interacting RNA (piRNA) pathway protects animal germline cells from transposable elements and other genomic invaders. Although the genome defense function of piRNAs has been well established, the mechanisms of their biogenesis remain poorly understood. In this issue of Genes \& Development, three groups identify novel factors required for piRNA biogenesis in Caenorhabditis elegans. These works greatly expand our understanding of the piRNA pathway in worms, highlighting both its shared and its unique properties.

piRNAs: genome defenders in the germline

PIWI-interacting RNAs (piRNAs) are predominantly germline-specific small RNAs found in animals that are characterized by their 20- to 35-nucleotide (nt) length, a 2'-Omethyl modification at the $3^{\prime}$ end, and a strong bias for uridine at the $5^{\prime}$ end $(1 \mathrm{U})$. piRNAs bind to PIWI subfamily proteins of the Argonaute (Ago) family and guide them via base-pairing to target RNAs. Like many Ago family proteins, PIWI proteins possess endonucleolytic "slicer" activity and can induce post-transcriptional silencing via cleavage of complementary RNAs (Brennecke et al. 2007; Gunawardane et al. 2007; De Fazio et al. 2011; Reuter et al. 2011). On the other hand, some nuclearlocalized PIWI proteins, such as fly Piwi and mouse Miwi2, are known to induce transcriptional silencing via either the heterochromatic histone mark H3K9me3 or DNA methylation in a manner that is independent of target cleavage (Aravin et al. 2008; Kuramochi-Miyagawa et al. 2008; De Fazio et al. 2011; Wang and Elgin 2011; Sienski et al. 2012).

The primary role of the piRNA pathway is to protect germline cells from genomic invaders such as transposons and other "nonself" elements, thereby ensuring transgenerational genome integrity. Indeed, the loss of PIWI proteins or piRNAs causes transposon activation and severe defects in gametogenesis (Cox et al. 1998; Deng and Lin

[Keywords: 21U RNA; C. elegans; piRNA]

${ }^{1}$ Corresponding author

E-mail tomari@iam.u-tokyo.ac.jp

Article is online at http://www.genesdev.org/cgi/doi/10.1101/gad.241323.114.
2002; Kuramochi-Miyagawa et al. 2004, 2008; Vagin et al. 2006; Aravin et al. 2007; Carmell et al. 2007; Houwing et al. 2007; Batista et al. 2008; Das et al. 2008; Li et al. 2009). While the genome defense function of piRNAs is well established and generally evolutionally conserved, organisms use piRNAs in remarkably flexible ways to achieve this function.

In fly ovaries and testes as well as in the prepachytene stage of mouse spermatogenesis, piRNAs are largely made from transposons and transposon-derived repetitive sequences, which target transposons themselves to silence (Fig. 1). In contrast, worms produce a pool of piRNAscalled 21U-RNAs in Caenorhabditis elegans (as they are precisely $21 \mathrm{nt}$ in length with $5^{\prime}$ uridine)-from intergenic and intronic regions of protein-coding genes (Ruby et al. 2006). 21U-RNAs are loaded into PRG-1, one of C. elegans PIWI proteins (Batista et al. 2008; Das et al. 2008; Wang and Reinke 2008). 21U-RNAs in PRG-1 tolerate several mismatches in the selection of their targets, allowing them to recognize virtually any sequence (Bagijn et al. 2012; Lee et al. 2012). On the other hand, the C. elegans Ago protein CSR-1 loads a broad repertoire of endogenous siRNAs named 22G-RNAs $(22$ $\mathrm{nt}$ in length with $5^{\prime}$ guanine) that are complementary to thousands of protein-coding genes expressed in the germline (Claycomb et al. 2009). Strikingly, CSR-1 acts to protect the protein-coding genes from PRG-1-mediated silencing and activate their expression (Lee et al. 2012; Shirayama et al. 2012; Conine et al. 2013; Seth et al. 2013; Wedeles et al. 2013). Thus, while the fly and mouse prepachytene piRNA systems distinguish self and nonself sequences to silence their enemies specifically, the worm 21U-RNA system scans every sequence in preparation for any potential threats and instead uses "tagging" by CSR-1-loaded 22G-RNAs to avoid selfattack (Fig. 1). Mice produce an enigmatic class of piRNAs, called pachytene piRNAs, which arise from unannotated

(C) 2014 Izumi and Tomari This article is distributed exclusively by Cold Spring Harbor Laboratory Press for the first six months after the full-issue publication date (see http://genesdev.cshlp.org/site/misc/terms.xhtml). After six months, it is available under a Creative Commons License (AttributionNonCommercial 4.0 International), as described at http://creativecommons. org/licenses/by-nc/4.0/. 

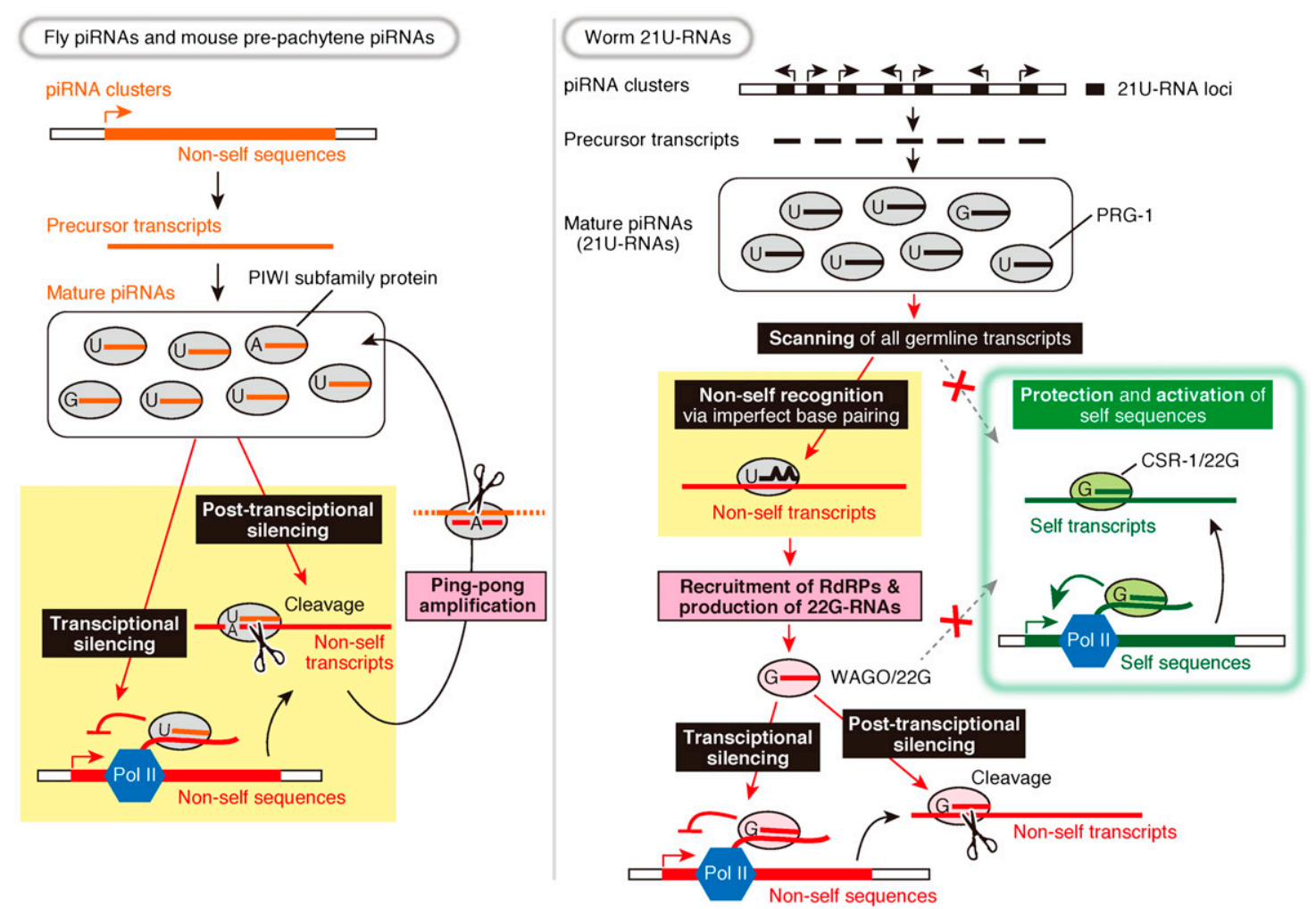

Figure 1. Similarities and differences between the piRNA pathway in flies and mice and that in worms. Fly and mouse piRNA clusters generate long single-stranded piRNA precursor transcripts from which multiple piRNAs are produced. The mature piRNAs are loaded into PIWI proteins that target transposon RNAs with sequence complementarity and silence them by cleavage (post-transcriptional silencing). The cleaved transposon RNAs become new piRNA precursors and amplify piRNAs against the transposons (ping-pong amplification). A subset of PIWI proteins is localized to the nucleus and induces transcriptional silencing. In contrast, each 21U-RNA locus codes a single 21U-RNA precursor in worms. 21U-RNAs in PRG-1 scan virtually all germline transcripts to detect potential harmful exogenous sequences, allowing several mismatches for recognition. To avoid self-attack, the CSR-1/22G-RNA pathway marks endogenous protein-coding genes for their protection from silencing and their activation. When the PRG-1/21U-RNA complex recognizes its targets, RNA-dependent RNA polymerases (RdRPs) are recruited, and another class of 22G-RNAs is produced. These 22G-RNAs are loaded into worm-specific Ago proteins (WAGOs) and silence their targets at both transcriptional and posttranscriptional levels. The role of piRNAs is different between flies/mice and worms (highlighted in yellow), but both achieve the same purpose of nonself silencing. Note that worms lack the ping-pong amplification but instead have the WAGO/22G-RNA pathway, thereby amplifying silencing signals (highlighted in pink).

intergenic regions during postnatal spermatogenesis; their targets remain unclear (Girard et al. 2006; Grivna et al. 2006).

\section{piRNA biogenesis in flies and mice}

Compared with microRNAs and siRNAs, much less is known about the mechanism of piRNA biogenesis. piRNAs are generally processed from longer, singlestranded precursor RNAs. Transcription of piRNA precursors requires specific transcription factors, which vary according to species and the precise type of piRNAs. For example, mouse pachytene piRNAs are transcribed by A-Myb, a master regulator of male meiosis (Li et al. 2013), while transcription from the fly flamenco locus, a major unistrand piRNA cluster, requires the transcription factor Cubitus interruotus (Goriaux et al. 2014). On the other hand, piRNA production from dual-strand clusters in flies depends on Rhino (a variant of heterochromatin protein 1
[HP1]) and Cutoff (homologous to the yeast transcription termination factor Rai1) (Klattenhoff et al. 2009; Pane et al. 2011). In all of these cases, piRNA precursors are produced by RNA polymerase II as long, continuous single-stranded transcripts, which can span $>100 \mathrm{~kb}$.

Processing of these long piRNA precursors into mature piRNAs can be divided into two distinct modes: primary processing and ping-pong amplification. Primary processing involves the endonucleolytic cleavage of precursor RNAs by Zucchini/MitoPLD (Ipsaro et al. 2012; Nishimasu et al. 2012). Next, a subset of PIWI proteins (e.g., Aubergine in flies) preferentially incorporates $1 \mathrm{U}$ fragments with the aid of the Hsp90 chaperone machinery (Kawaoka et al. 2011; Olivieri et al. 2012; Preall et al. 2012; Izumi et al. 2013). Subsequently, their $3^{\prime}$ ends are trimmed by a $3^{\prime}$-to-5' exonuclease named Trimmer (whose identity remains unknown) to the mature piRNA length (Kawaoka et al. 2011), followed by 2'-O-methylation by Henl (Horwich et al. 2007; Kirino and Mourelatos 2007; Ohara et al. 2007; 
Saito et al. 2007). Thus, the $1 \mathrm{U}$ bias is a molecular signature of primary piRNAs.

Ping-pong amplification, or the secondary piRNA biogenesis pathway, drastically increases the production of piRNAs and is coupled with slicer-dependent destruction of active transposons. In this scheme, primary PIWI proteins first cleave their complementary target RNAs across from the 10th position of their $1 \mathrm{U}$ piRNA guides. The 3' fragments of this cleavage possess adenine at the 10th position (10A) and are then incorporated into another subset of PIWI proteins (e.g., Ago3 in flies) as new piRNA precursors. Finally, their 3' ends are matured by trimming and 2'-O-methylation, as in the primary processing pathway. The resultant secondary piRNAs can, in turn, cleave their complementary target RNAs (from which primary piRNAs originate), thereby fueling the amplification loop. Accordingly, primary and secondary piRNAs show precisely 10-nt overlaps at their 5' ends, with characteristic $1 \mathrm{U}$ and 10A signatures, respectively (Aravin et al. 2007, 2008; Brennecke et al. 2007; Gunawardane et al. 2007).

In addition to PIWI proteins, many other proteins are required for the production of piRNAs, including Tudor family proteins and ATP-dependent RNA helicases. Although the precise role of each factor is still unclear, their involvement in the piRNA biogenesis is fundamentally conserved between flies and mice (Malone et al. 2009; Reuter et al. 2009; Shoji et al. 2009; Vagin et al. 2009; Frost et al. 2010; Kuramochi-Miyagawa et al. 2010; Olivieri et al. 2010, 2012; Saito et al. 2010; Zheng et al. 2010; Handler et al. 2011; Liu et al. 2011; Watanabe et al. 2011; Ipsaro et al. 2012; Nishimasu et al. 2012; Preall et al. 2012; Xiol et al. 2012; Pandey et al. 2013; Saxe et al. 2013).

\section{piRNA biogenesis in C. elegans}

Like fly and mouse piRNAs, precursors of C. elegans 21URNAs are first transcribed by RNA polymerase II. Unlike fly and mouse piRNAs, however, each 21U-RNA locus in $C$. elegans produces an independent short transcript of merely $\sim 26$ nt (Ruby et al. 2006; Cecere et al. 2012). 21U-RNAs can be divided into two groups: type I and the less abundant type II (Fig. 2; Gu et al. 2012). Type I 21U-RNA loci accumulate within two piRNA cluster regions on chromosome IV and have a conserved 8-nt motif (CTGTTTCA) located $\sim 40 \mathrm{nt}$ upstream of each locus. The motif is recognized by Forkhead (FKH) family transcription factors and is essential for type I 21U-RNA production (Ruby et al. 2006; Cecere et al. 2012). In contrast, type II 21U-RNA loci have no apparent upstream motif and are dispersed throughout the genome (Gu et al. 2012). Regardless of their types, precursors of 21URNAs begin precisely $2 \mathrm{nt}$ upstream of mature 21U-RNAs (Gu et al. 2012). They are thought to first be decapped, the 5' 2-nt region is removed, and then they are loaded into PRG1. Subsequently, the $3^{\prime}$ end is believed to be shortened by $\sim 3 \mathrm{nt}$ to generate the mature 21 -nt length and the $2^{\prime}-O$ methylated by HENN-1, like piRNAs are in other animals (Fig. 2; Billi et al. 2012; Kamminga et al. 2012; Montgomery et al. 2012).

Unlike flies and mice, C. elegans does not produce secondary piRNAs via the slicer-dependent ping-pong amplification loop. In fact, the slicer activity of PRG-1 is dispensable for target silencing (Bagijn et al. 2012; Lee

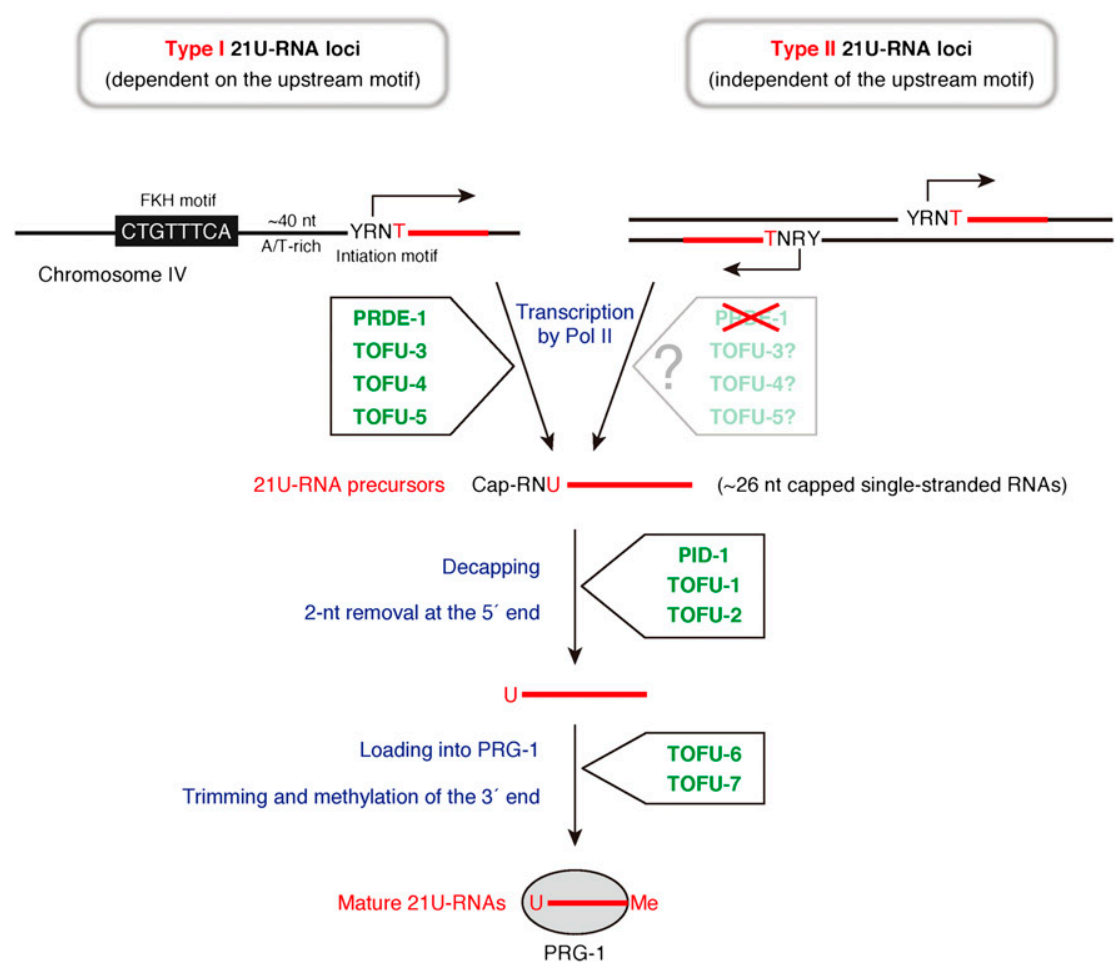

Figure 2. Model of the 21U-RNA biogenesis and novel factors required for each process. C. elegans 21U-RNA loci are divided into two groups, type I and type II, according to the presence of the upstream conserved 8-nt motif, which is recognized by FKH family transcription factors. Type I 21U-RNA loci have this motif and are clustered on chromosome IV. On the other hand, type II 21U-RNA loci lack the upstream motif and frequently present in both directions on the genome. The $\mathrm{YR}$ motif $(\mathrm{Y}=\mathrm{C}$ or $\mathrm{T} ; \mathrm{R}=\mathrm{A}$ or $\mathrm{G})$ is important for efficient transcription initiation. Each 21U-RNA locus produces 26-nt capped 21U-RNA precursors. After initial processing, including decapping and removal of $2 \mathrm{nt}$ at the $5^{\prime}$ end, the precursor RNA is thought to be loaded into PRG-1, and its $3^{\prime}$ end is further processed by trimming. The newly identified 21U-RNA biogenesis factors (green) and the steps where they function are shown. 
et al. 2012). Instead, target recognition by 21 U-RNAs in PRG-1 recruits RNA-dependent RNA polymerases and triggers massive production of secondary siRNAs (22GRNAs). These 22G-RNAs are loaded into worm-specific Agos (WAGOs), which include the nuclear Ago protein HRDE-1 (WAGO-9) and mediate target silencing at both post-transcriptional and transcriptional levels (Fig. 1; Das et al. 2008; Bagijn et al. 2012; Lee et al. 2012). The selfprotective CSR-1/22G-RNA pathway can counteract both types of silencing by WAGO-loaded 22G-RNAs (Lee et al. 2012; Shirayama et al. 2012; Conine et al. 2013; Seth et al. 2013; Wedeles et al. 2013). Strikingly, once genes are either silenced by WAGO/22G-RNAs or activated by CSR-1/22G-RNAs, their silent/active status can be stably inherited over generations and thereby mediates an epigenetic memory (Ashe et al. 2012; Luteijn et al. 2012; Shirayama et al. 2012; Conine et al. 2013; Seth et al. 2013; Wedeles et al. 2013). Thus, C. elegans uses two types of 22G-RNAs with precisely opposite functions: CSR-1-loaded 22G-RNAs for self-protection and activation upstream of 21U-RNAs and WAGO-loaded 22G-RNAs for nonself silencing downstream from 21U-RNAs (Fig. 1).

\section{Novel piRNA biogenesis factors in C. elegans}

\section{Twenty-One-u Fouled Ups (TOFUs)}

While an understanding of the worm piRNA (21U-RNA) pathway is emerging, little is currently known about factors required for their production. In fact, most of piRNA biogenesis factors identified in other animals, including the endonuclease Zucchini/MitoPLD, are not conserved in worms. In this issue of Genes \& Development, three groups (de Albuquerue et al. 2014; Goh et al. 2014; Weick et al. 2014) report on their discoveries of novel factors that are involved in the production of $21 \mathrm{U}-\mathrm{RNAs}$ in C. elegans.

Goh et al. (2014) performed an RNAi screen covering $>80 \%$ of annotated C. elegans protein-coding genes and identified 22 genes that affect mature 21U-RNA levels (named TOFUs). More than half of identified TOFU genes have no apparent orthologs in other animals. Interestingly, genome-wide RNAi screenings for piRNA factors in flies did not hit exiting TOFU homologs (Czech et al. 2013; Muerdter et al. 2013). To determine how each TOFU functions, Goh et al. (2014) focused on the top seven TOFUs with the strongest reduction in mature 21U-RNA levels (TOFU1-7) and analyzed 21U-RNA precursor levels upon their depletion. The investigators observed a clear accumulation of $\sim 26-n t$ 21U-RNA precursors in the absence of TOFU-1 and TOFU-2, indicating that these two factors are required for processing after precursor RNA production (Fig. 2). Because both proteins have an ATP-binding domain and TOFU-2 has similarity to the DEAD-box helicase DDX1 in mammals, these are expected to function in ATP-dependent processes, perhaps involving rearrangement of RNA-protein complexes. On the other hand, depletion of TOFU3-5 resulted in a significant reduction of precursor RNAs. Therefore, these factors are required for the production or stability of 21U-RNA precursors (Fig. 2). TOFU-3 is a SUMO-related protease, and its mammalian homolog, SENP7, is known to directly interact with $\mathrm{HP} 1 \alpha$ and regulate its localization to pericentric heterochromatin (Maison et al. 2012). TOFU-5 has a Swi3, Ada2, N-CoR, and TFIIIB (SANT) domain, a DNA-binding domain structurally related to that of $\mathrm{Myb}$ and found in various transcription regulatory factors. Thus, these factors presumably play a role in the transcription of precursors of abundant type I 21U-RNAs, although the investigators did not explicitly examine whether TOFU3-5 are also involved in the production of type II 21U-RNAs, a small population of 21U-RNAs that does not have the conserved upstream motif. Depletion of the other two TOFUs (TOFU-6 and TOFU-7) decreased mature 21U-RNA levels twofold to threefold but did not have any substantial effect on precursor RNA levels. Accordingly, the investigators speculate that TOFU-6 and TOFU-7 function downstream from initial processing of 21U-RNA precursors; e.g., PRG-1loading or localization of $5^{\prime}$ removed precursors (Fig. 2). Since TOFU-6 and TOFU-7 have an RNA recognition motif (RRM) and a hnRNP K homology (KH) domain, respectively, these factors presumably bind to precursor RNAs. Furthermore, TOFU-6 has a Tudor-like domain, implying a commonality with fly and mouse piRNA biogenesis pathways.

Goh et al. (2014) also found seven suppressor genes of 21U-RNA production from their screen. Intriguingly, one of them is CSR-1, the Ago protein that loads 22G-RNAs to protect protein-coding transcripts, including prg-1 mRNA, from 21U-RNA-mediated silencing, as described above (Lee et al. 2012; Shirayama et al. 2012; Conine et al. 2013; Seth et al. 2013; Wedeles et al. 2013). Although 22G-RNAs in CSR-1 are thought to bind and mark self transcripts without causing their silencing, the investigators observed an elevation of prg-1 mRNA in csr-1 RNAi and csr-1 mutants. Up-regulation of prg-1 mRNA and a representative $21 \mathrm{U}-\mathrm{RNA}$ was also seen in the mutants of other CSR-1/22G-RNA pathway factors, EGO-1 (an RNA-dependent RNA polymerase that synthesizes CSR-1-type 22G-RNAs) and EKL-1 (a Tudor domain protein required for the production of both CSR-1- and WAGO-type 22G-RNAs) (Claycomb et al. 2009; Gu et al. 2009). The investigators discuss the possibility that the CSR-1/22G-RNA pathway normally represses the prg-1 mRNA level, while a previous study showed no significant change in the protein level of PRG-1 in the csr-1 mutant (Claycomb et al. 2009). Although further analysis is warranted, the notion that the CSR-1/ 22G-RNA pathway negatively regulates the PRG-1/21URNA pathway highlights the intricate relationship between the two pathways.

\section{piRNA-induced silencing defective-1 (pid-1)}

de Albuquerue et al (2014) performed ethyl methanesulfonate (EMS) screening with a 21U-RNA sensor and identified PID-1. PID-1 is an uncharacterized germline-specific small protein with no known orthologs in other animals. In pid-1 mutants, mature 21U-RNAs derived from both type I and type II loci were markedly reduced, but precursor RNAs were accumulated. Thus, PID-1 is a general 
factor that is required for 21U-RNA biogenesis, acting in a process downstream from precursor RNA production (Fig. 2). In pid-1 mutants, a small amount of mature $21 \mathrm{U}$ RNAs with normal properties are still generated, and the structure of accumulated precursor RNAs is also normal. These observations suggest that PID-1 deletion slows down the processing rate of precursor RNAs. PID-1 mostly localizes to the cytoplasm, but a small fraction is present in the nucleus. In addition, PID-1 has both a putative nuclear localization signal (NLS) and a nuclear export signal (NES). Based on these protein features, de Albuquerue et al. (2014) discuss the possibility that PID-1 is involved in the transport of precursor RNAs to the processing sites. Given that PID-1 has no apparent RNAbinding motif, additional factors are expected to participate in this process. Further characterization of PID-1 and its potential link to other factors will be needed to understand the exact function of PID-1.

\section{piRNA silencing defective 1 (prde-1)}

Weick et al. (2014) also conducted EMS mutagenesis screening using a 21U-RNA sensor and identified PRDE-1. PRDE-1 has a protein kinase-like domain, but amino acid residues critical for ATP binding in the kinase domain are not conserved. No clear orthologs of PRDE-1 are found in other animals. PRDE-1 is exclusively expressed in germline cells and localizes to specific nuclear foci. Using DNA-FISH in combination with immunostaining, the investigators revealed that PRDE-1 associates with the 21U-RNA cluster regions on chromosome IV. In prde-1 mutants, a pronounced reduction of mature type I $21 \mathrm{U}$ RNAs and their precursor RNAs was observed without apparent effect on type II 21 U-RNAs. Thus, PRDE-1 is a factor specifically required for production of type I 21U-RNA precursors (Fig. 2). Considering its characteristic localization to chromosome IV, the investigators discuss a model in which PRDE-1 plays a role in recruiting RNA polymerase II to the FKH motif. Future studies examining the relationship between PRDE-1 and FKH transcription factors will clarify the exact role of PRDE-1 in type I 21U-RNA biogenesis.

Weick et al. (2014) compared the change in gene expression between prg-1 and prde-1 mutants and revealed the functional difference between type I and type II 21URNAs. Focusing on genes up-regulated in the prg-1 mutant but not in the prde-1 mutant, Weick et al. (2014) discovered a significant enrichment in innate immune genes. These findings provide insights into the evolution of the two types of 21U-RNAs and the regulation of gene expression by the 21U-RNA pathway. Their data also demonstrate that type II 21U-RNAs act upstream of WAGO/22G-RNAs, similar to type I $21 \mathrm{U}-\mathrm{RNAs}$.

\section{Concluding remarks}

Taken together, these three studies elucidate novel factors required for 21U-RNA production, representing the first step in understanding the mechanism of 21U-RNA biogenesis. Identification of PRDE-1, a factor exclusively required for type I 21U-RNA production, underscores that there are two distinct classes of piRNAs in worms. Most of the identified 21U-RNA biogenesis factors do not have orthologs in other species, perhaps reflecting the elegant interplay between the 21U-piRNA pathway and the two distinct 22G endogenous siRNA pathways as a means to specifically and efficiently silence nonself genes in worms. Moreover, the genes identified by the three screenings did not overlap, implying that there are even more 21U-RNA-related factors to be revealed. Obviously, the next challenge is to clarify the role of each factor and the connections among them. Also of worthwhile study is the regulation of gene expression by the piRNA pathway in worms. As indicated by Weick et al. (2014) the two types of 21U-RNAs target different sets of genes, with type II 21U-RNAs specifically repressing innate immune genes. In this regard, it would be interesting to examine whether the production of type II 21U-RNAs is in turn regulated by innate immune responses. Given that the CSR-1/22G-RNA pathway negatively regulates the 21URNA production as reported by Goh et al. (2014), further studies focusing on the regulation of the piRNA pathway and its relationship with other small RNA pathways will be important to understand the biological significance of gene expression control by the piRNA pathway in C. elegans.

\section{Acknowledgments}

We thank Martin Simard (Laval University) and the members of the Tomari laboratory for critical comments on the manuscript. This work was supported in part by a Grant-in-Aid for Scientific Research on Innovative Areas ("Functional machinery for noncoding RNAs," grant no. 21115002) from the Ministry of Education, Culture, Sports, Science, and Technology of Japan to Y.T., and a post-doctoral fellowship from the Japan Society for the Promotion of Science to N.I.

\section{References}

Aravin AA, Sachidanandam R, Girard A, Fejes-Toth K, Hannon GJ. 2007. Developmentally regulated piRNA clusters implicate MILI in transposon control. Science 316: 744-747.

Aravin AA, Sachidanandam R, Bourc'his D, Schaefer C, Pezic D, Toth KF, Bestor T, Hannon GJ. 2008. A piRNA pathway primed by individual transposons is linked to de novo DNA methylation in mice. Mol Cell 31: 785-799.

Ashe A, Sapetschnig A, Weick EM, Mitchell J, Bagijn MP, Cording AC, Doebley AL, Goldstein LD, Lehrbach NJ, Le Pen J, et al. 2012. piRNAs can trigger a multigenerational epigenetic memory in the germline of C. elegans. Cell 150: 88-99.

Bagijn MP, Goldstein LD, Sapetschnig A, Weick EM, Bouasker S, Lehrbach NJ, Simard MJ, Miska EA. 2012. Function, targets, and evolution of Caenorhabditis elegans piRNAs. Science 337: 574-578.

Batista PJ, Ruby JG, Claycomb JM, Chiang R, Fahlgren N, Kasschau KD, Chaves DA, Gu W, Vasale JJ, Duan S, et al. 2008. PRG-1 and 21U-RNAs interact to form the piRNA complex required for fertility in C. elegans. Mol Cell 31: 67-78.

Billi AC, Alessi AF, Khivansara V, Han T, Freeberg M, Mitani S, Kim JK. 2012. The Caenorhabditis elegans HEN1 ortholog, HENN-1, methylates and stabilizes select subclasses of germline small RNAs. PLoS Genet 8: e1002617. 
Brennecke J, Aravin AA, Stark A, Dus M, Kellis M, Sachidanandam R, Hannon GJ. 2007. Discrete small RNA-generating loci as master regulators of transposon activity in Drosophila. Cell 128: 1089-1103.

Carmell MA, Girard A, van de Kant HJ, Bourc'his D, Bestor TH, de Rooij DG, Hannon GJ. 2007. MIWI2 is essential for spermatogenesis and repression of transposons in the mouse male germline. Dev Cell 12: 503-514.

Cecere G, Zheng GX, Mansisidor AR, Klymko KE, Grishok A. 2012. Promoters recognized by forkhead proteins exist for individual 21U-RNAs. Mol Cell 47: 734-745.

Claycomb JM, Batista PJ, Pang KM, Gu W, Vasale JJ, van Wolfswinkel JC, Chaves DA, Shirayama M, Mitani S, Ketting $\mathrm{RF}$, et al. 2009. The Argonaute CSR-1 and its 22G-RNA cofactors are required for holocentric chromosome segregation. Cell 139: 123-134.

Conine CC, Moresco JJ, Gu W, Shirayama M, Conte D Jr, Yates JR 3rd, Mello CC. 2013. Argonautes promote male fertility and provide a paternal memory of germline gene expression in C. elegans. Cell 155: 1532-1544.

Cox DN, Chao A, Baker J, Chang L, Qiao D, Lin H. 1998. A novel class of evolutionarily conserved genes defined by piwi are essential for stem cell self-renewal. Genes Dev 12: 3715-3727.

Czech B, Preall JB, McGinn J, Hannon GJ. 2013. A transcriptome-wide RNAi screen in the Drosophila ovary reveals factors of the germline piRNA pathway. Mol Cell 50: 749-761.

Das PP, Bagijn MP, Goldstein LD, Woolford JR, Lehrbach NJ, Sapetschnig A, Buhecha HR, Gilchrist MJ, Howe KL, Stark R, et al. 2008. Piwi and piRNAs act upstream of an endogenous siRNA pathway to suppress Tc3 transposon mobility in the Caenorhabditis elegans germline. Mol Cell 31: 79-90.

de Albuquerque BFM, Luteijn MJ, Cordeiro Rodrigues RJ, van Bergeijk P, Waaijers S, Kaaij LJT, Klein H, Boxem M, Ketting RF. 2014. PID-1 is a novel factor that operates during $21 \mathrm{U}$ RNA biogenesis in Caenorhabditis elegans. Genes Dev (this issue). doi: 10.1101/gad.238220.114.

De Fazio S, Bartonicek N, Di Giacomo M, Abreu-Goodger C, Sankar A, Funaya C, Antony C, Moreira PN, Enright AJ, O'Carroll D. 2011. The endonuclease activity of Mili fuels piRNA amplification that silences LINE1 elements. Nature 480: 259-263.

Deng W, Lin H. 2002. miwi, a murine homolog of piwi, encodes a cytoplasmic protein essential for spermatogenesis. Dev Cell 2: 819-830.

Frost RJ, Hamra FK, Richardson JA, Qi X, Bassel-Duby R, Olson EN. 2010. MOV10L1 is necessary for protection of spermatocytes against retrotransposons by Piwi-interacting RNAs. Proc Natl Acad Sci 107: 11847-11852.

Girard A, Sachidanandam R, Hannon GJ, Carmell MA. 2006. A germline-specific class of small RNAs binds mammalian Piwi proteins. Nature 442: 199-202.

Goh WSS, Seah JWE, Harrison EJ, Chen C, Hammell CM, Hannon GJ. 2014. A genome-wide RNAi screen identifies factors required for distinct stages of C. elegans piRNA biogenesis. Genes Dev (this issue). doi: 10.1101/gad.235622.113.

Goriaux C, Desset S, Renaud Y, Vaury C, Brasset E. 2014. Transcriptional properties and splicing of the flamenco piRNA cluster. EMBO Rep. doi: 10.1002/embr.201227898.

Grivna ST, Beyret E, Wang Z, Lin H. 2006. A novel class of small RNAs in mouse spermatogenic cells. Genes Dev 20: 17091714.

Gu W, Shirayama M, Conte D Jr, Vasale J, Batista PJ, Claycomb JM, Moresco JJ, Youngman EM, Keys J, Stoltz MJ, et al. 2009. Distinct argonaute-mediated 22G-RNA pathways direct genome surveillance in the C. elegans germline. Mol Cell 36: $231-244$.
Gu W, Lee HC, Chaves D, Youngman EM, Pazour GJ, Conte D Jr, Mello CC. 2012. CapSeq and CIP-TAP identify Pol II start sites and reveal capped small RNAs as C. elegans piRNA precursors. Cell 151: 1488-1500.

Gunawardane LS, Saito K, Nishida KM, Miyoshi K, Kawamura Y, Nagami T, Siomi H, Siomi MC. 2007. A slicer-mediated mechanism for repeat-associated siRNA 5 ' end formation in Drosophila. Science 315: 1587-1590.

Handler D, Olivieri D, Novatchkova M, Gruber FS, Meixner K, Mechtler K, Stark A, Sachidanandam R, Brennecke J. 2011. A systematic analysis of Drosophila TUDOR domaincontaining proteins identifies Vreteno and the Tdrd12 family as essential primary piRNA pathway factors. EMBO $J \mathbf{3 0}$ : 3977-3993.

Horwich MD, Li C, Matranga C, Vagin V, Farley G, Wang P, Zamore PD. 2007. The Drosophila RNA methyltransferase, DmHen1, modifies germline piRNAs and single-stranded siRNAs in RISC. Curr Biol 17: 1265-1272.

Houwing S, Kamminga LM, Berezikov E, Cronembold D, Girard A, van den Elst H, Filippov DV, Blaser H, Raz E, Moens CB, et al. 2007. A role for Piwi and piRNAs in germ cell maintenance and transposon silencing in Zebrafish. Cell 129: 69-82.

Ipsaro JJ, Haase AD, Knott SR, Joshua-Tor L, Hannon GJ. 2012. The structural biochemistry of Zucchini implicates it as a nuclease in piRNA biogenesis. Nature 491: 279-283.

Izumi N, Kawaoka S, Yasuhara S, Suzuki Y, Sugano S, Katsuma S, Tomari Y. 2013. Hsp90 facilitates accurate loading of precursor piRNAs into PIWI proteins. RNA 19: 896-901.

Kamminga LM, van Wolfswinkel JC, Luteijn MJ, Kaaij LJ, Bagijn MP, Sapetschnig A, Miska EA, Berezikov E, Ketting RF. 2012. Differential impact of the HEN1 homolog HENN-1 on $21 \mathrm{U}$ and 26G RNAs in the germline of Caenorhabditis elegans. PLoS Genet 8: e1002702.

Kawaoka S, Izumi N, Katsuma S, Tomari Y. 2011. 3' end formation of PIWI-interacting RNAs in vitro. Mol Cell 43: 1015-1022.

Kirino Y, Mourelatos Z. 2007. Mouse Piwi-interacting RNAs are 2'-O-methylated at their 3' termini. Nat Struct Mol Biol 14: 347-348.

Klattenhoff C, Xi H, Li C, Lee S, Xu J, Khurana JS, Zhang F, Schultz N, Koppetsch BS, Nowosielska A, et al. 2009. The Drosophila HP1 homolog Rhino is required for transposon silencing and piRNA production by dual-strand clusters. Cell 138: 1137-1149.

Kuramochi-Miyagawa S, Kimura T, Ijiri TW, Isobe T, Asada N, Fujita Y, Ikawa M, Iwai N, Okabe M, Deng W, et al. 2004. Mili, a mammalian member of piwi family gene, is essential for spermatogenesis. Development 131: 839-849.

Kuramochi-Miyagawa S, Watanabe $\mathrm{T}$, Gotoh $\mathrm{K}$, Totoki $\mathrm{Y}$, Toyoda A, Ikawa M, Asada N, Kojima K, Yamaguchi Y, Ijiri TW, et al. 2008. DNA methylation of retrotransposon genes is regulated by Piwi family members MILI and MIWI2 in murine fetal testes. Genes Dev 22: 908-917.

Kuramochi-Miyagawa S, Watanabe T, Gotoh K, Takamatsu K, Chuma S, Kojima-Kita K, Shiromoto Y, Asada N, Toyoda A, Fujiyama A, et al. 2010. MVH in piRNA processing and gene silencing of retrotransposons. Genes Dev 24: 887-892.

Lee HC, Gu W, Shirayama M, Youngman E, Conte D Jr, Mello CC. 2012. C. elegans piRNAs mediate the genome-wide surveillance of germline transcripts. Cell 150: 78-87.

Li C, Vagin VV, Lee S, Xu J, Ma S, Xi H, Seitz H, Horwich MD, Syrzycka M, Honda BM, et al. 2009. Collapse of germline piRNAs in the absence of Argonaute3 reveals somatic piRNAs in flies. Cell 137: 509-521.

Li XZ, Roy CK, Dong X, Bolcun-Filas E, Wang J, Han BW, Xu J, Moore MJ, Schimenti JC, Weng Z, et al. 2013. An ancient 
transcription factor initiates the burst of piRNA production during early meiosis in mouse testes. Mol Cell 50: 67-81.

Liu L, Qi H, Wang J, Lin H. 2011. PAPI, a novel TUDOR-domain protein, complexes with AGO3, ME31B and TRAL in the nuage to silence transposition. Development 138: 18631873.

Luteijn MJ, van Bergeijk P, Kaaij LJ, Almeida MV, Roovers EF, Berezikov E, Ketting RF. 2012. Extremely stable Piwi-induced gene silencing in Caenorhabditis elegans. EMBO J 31: 3422-3430.

Maison C, Romeo K, Bailly D, Dubarry M, Quivy JP, Almouzni G. 2012. The SUMO protease SENP7 is a critical component to ensure HP1 enrichment at pericentric heterochromatin. Nat Struct Mol Biol 19: 458-460.

Malone CD, Brennecke J, Dus M, Stark A, McCombie WR, Sachidanandam R, Hannon GJ. 2009. Specialized piRNA pathways act in germline and somatic tissues of the Drosophila ovary. Cell 137: 522-535.

Montgomery TA, Rim YS, Zhang C, Dowen RH, Phillips CM, Fischer SE, Ruvkun G. 2012. PIWI associated siRNAs and piRNAs specifically require the Caenorhabditis elegans HEN1 ortholog henn-1. PLoS Genet 8: e1002616.

Muerdter F, Guzzardo PM, Gillis J, Luo Y, Yu Y, Chen C, Fekete R, Hannon GJ. 2013. A genome-wide RNAi screen draws a genetic framework for transposon control and primary piRNA biogenesis in Drosophila. Mol Cell 50: 736-748.

Nishimasu H, Ishizu H, Saito K, Fukuhara S, Kamatani MK, Bonnefond L, Matsumoto N, Nishizawa T, Nakanaga K, Aoki J, et al. 2012. Structure and function of Zucchini endoribonuclease in piRNA biogenesis. Nature 491: 284-287.

Ohara T, Sakaguchi Y, Suzuki T, Ueda H, Miyauchi K. 2007. The $3^{\prime}$ termini of mouse Piwi-interacting RNAs are 2'-O-methylated. Nat Struct Mol Biol 14: 349-350.

Olivieri D, Sykora MM, Sachidanandam R, Mechtler K, Brennecke J. 2010. An in vivo RNAi assay identifies major genetic and cellular requirements for primary piRNA biogenesis in Drosophila. EMBO J 29: 3301-3317.

Olivieri D, Senti KA, Subramanian S, Sachidanandam R, Brennecke J. 2012. The cochaperone shutdown defines a group of biogenesis factors essential for all piRNA populations in Drosophila. Mol Cell 47: 954-969.

Pandey RR, Tokuzawa Y, Yang Z, Hayashi E, Ichisaka T, Kajita S, Asano Y, Kunieda T, Sachidanandam R, Chuma S, et al. 2013. Tudor domain containing 12 (TDRD12) is essential for secondary PIWI interacting RNA biogenesis in mice. Proc Natl Acad Sci 110: 16492-16497.

Pane A, Jiang P, Zhao DY, Singh M, Schupbach T. 2011. The Cutoff protein regulates piRNA cluster expression and piRNA production in the Drosophila germline. EMBO J 30: 4601-4615.

Preall JB, Czech B, Guzzardo PM, Muerdter F, Hannon GJ. 2012. shutdown is a component of the Drosophila piRNA biogenesis machinery. RNA 18: 1446-1457.

Reuter M, Chuma S, Tanaka T, Franz T, Stark A, Pillai RS. 2009. Loss of the Mili-interacting Tudor domain-containing protein-1 activates transposons and alters the Mili-associated small RNA profile. Nat Struct Mol Biol 16: 639-646.

Reuter M, Berninger P, Chuma S, Shah H, Hosokawa M, Funaya C, Antony C, Sachidanandam R, Pillai RS. 2011. Miwi catalysis is required for piRNA amplification-independent LINE1 transposon silencing. Nature 480: 264-267.

Ruby JG, Jan C, Player C, Axtell MJ, Lee W, Nusbaum C, Ge H, Bartel DP. 2006. Large-scale sequencing reveals 21U-RNAs and additional microRNAs and endogenous siRNAs in $C$. elegans. Cell 127: 1193-1207.

Saito K, Sakaguchi Y, Suzuki T, Siomi H, Siomi MC. 2007. Pimet, the Drosophila homolog of HEN1, mediates 2'-O-meth- ylation of Piwi- interacting RNAs at their $3^{\prime}$ ends. Genes Dev 21: 1603-1608.

Saito K, Ishizu H, Komai M, Kotani H, Kawamura Y, Nishida KM, Siomi H, Siomi MC. 2010. Roles for the Yb body components Armitage and $\mathrm{Yb}$ in primary piRNA biogenesis in Drosophila. Genes Dev 24: 2493-2498.

Saxe JP, Chen M, Zhao H, Lin H. 2013. Tdrkh is essential for spermatogenesis and participates in primary piRNA biogenesis in the germline. EMBO I 32: 1869-1885.

Seth M, Shirayama M, Gu W, Ishidate T, Conte D Jr, Mello CC. 2013. The C. elegans CSR-1 argonaute pathway counteracts epigenetic silencing to promote germline gene expression. Dev Cell 27: 656-663.

Shirayama M, Seth M, Lee HC, Gu W, Ishidate T, Conte D Jr, Mello CC. 2012. piRNAs initiate an epigenetic memory of nonself RNA in the C. elegans germline. Cell 150: 65-77.

Shoji M, Tanaka T, Hosokawa M, Reuter M, Stark A, Kato Y, Kondoh G, Okawa K, Chujo T, Suzuki T, et al. 2009. The TDRD9-MIWI2 complex is essential for piRNA-mediated retrotransposon silencing in the mouse male germline. Dev Cell 17: 775-787.

Sienski G, Donertas D, Brennecke J. 2012. Transcriptional silencing of transposons by Piwi and maelstrom and its impact on chromatin state and gene expression. Cell 151: 964-980.

Vagin VV, Sigova A, Li C, Seitz H, Gvozdev V, Zamore PD. 2006. A distinct small RNA pathway silences selfish genetic elements in the germline. Science 313: 320-324.

Vagin VV, Wohlschlegel J, Qu J, Jonsson Z, Huang X, Chuma S, Girard A, Sachidanandam R, Hannon GJ, Aravin AA. 2009. Proteomic analysis of murine Piwi proteins reveals a role for arginine methylation in specifying interaction with Tudor family members. Genes Dev 23: 1749-1762.

Wang SH, Elgin SC. 2011. Drosophila Piwi functions downstream of piRNA production mediating a chromatin-based transposon silencing mechanism in female germ line. Proc Natl Acad Sci 108: 21164-21169.

Wang G, Reinke V. 2008. A C. elegans Piwi, PRG-1, regulates 21U-RNAs during spermatogenesis. Curr Biol 18: 861-867.

Watanabe T, Chuma S, Yamamoto Y, Kuramochi-Miyagawa S, Totoki Y, Toyoda A, Hoki Y, Fujiyama A, Shibata T, Sado T, et al. 2011. MITOPLD is a mitochondrial protein essential for nuage formation and piRNA biogenesis in the mouse germline. Dev Cell 20: 364-375.

Wedeles CJ, Wu MZ, Claycomb JM. 2013. Protection of germline gene expression by the C. elegans Argonaute CSR-1. Dev Cell 27: 664-671.

Weick EM, Sarkies P, Silva N, Chen RA, Moss SMM, Cording AC, Ahringer J, Martinez-Perez E, Miska EA. 2014. PRDE-1 is a nuclear factor essential for the biogenesis of Ruby motifdependent piRNAs in C. elegans. Genes Dev (this issue). doi: 10.1101/gad.238105.114.

Xiol J, Cora E, Koglgruber R, Chuma S, Subramanian S, Hosokawa M, Reuter M, Yang Z, Berninger P, Palencia A, et al. 2012. A role for Fkbp6 and the chaperone machinery in piRNA amplification and transposon silencing. Mol Cell 47: 970979.

Zheng K, Xiol J, Reuter M, Eckardt S, Leu NA, McLaughlin KJ, Stark A, Sachidanandam R, Pillai RS, Wang PJ. 2010. Mouse MOV10L1 associates with Piwi proteins and is an essential component of the Piwi-interacting RNA (piRNA) pathway. Proc Natl Acad Sci 107: 11841-11846. 


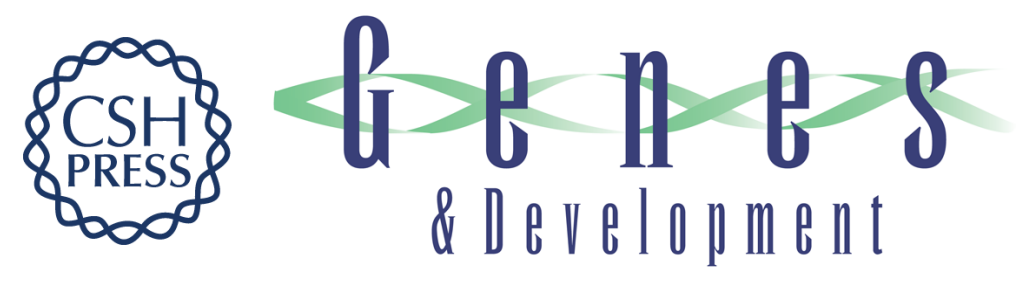

\title{
Diversity of the piRNA pathway for nonself silencing: worm-specific piRNA biogenesis factors
}

\author{
Natsuko Izumi and Yukihide Tomari
}

Genes Dev. 2014, 28:

Access the most recent version at doi:10.1101/gad.241323.114

\section{Related Content PID-1 is a novel factor that operates during 21U-RNA biogenesis in Caenorhabditis elegans \\ Bruno F.M. de Albuquerque, Maartje J. Luteijn, Ricardo J. Cordeiro Rodrigues, et al. Genes Dev. April , 2014 28: 683-688 PRDE-1 is a nuclear factor essential for the biogenesis of Ruby motif-dependent piRNAs in C. elegans Eva-Maria Weick, Peter Sarkies, Nicola Silva, et al. Genes Dev. April, 2014 28: 783-796 A genome-wide RNAi screen identifies factors required for distinct stages of $\mathrm{C}$. elegans piRNA biogenesis Wee-Siong Sho Goh, Jun Wen Eugene Seah, Emily J. Harrison, et al. Genes Dev. April , 2014 28: 797-807}

References This article cites 68 articles, 24 of which can be accessed free at: http://genesdev.cshlp.org/content/28/7/665.full.html\#ref-list-1

Articles cited in:

http://genesdev.cshlp.org/content/28/7/665.full.htmI\#related-urls

Creative This article is distributed exclusively by Cold Spring Harbor Laboratory Press for the first Commons License

Email Alerting six months after the full-issue publication date (see http://genesdev.cshlp.org/site/misc/terms.xhtml). After six months, it is available under a Creative Commons License (Attribution-NonCommercial 4.0 International), as described at http://creativecommons.org/licenses/by-nc/4.0/.

Service

Receive free email alerts when new articles cite this article - sign up in the box at the top right corner of the article or click here.

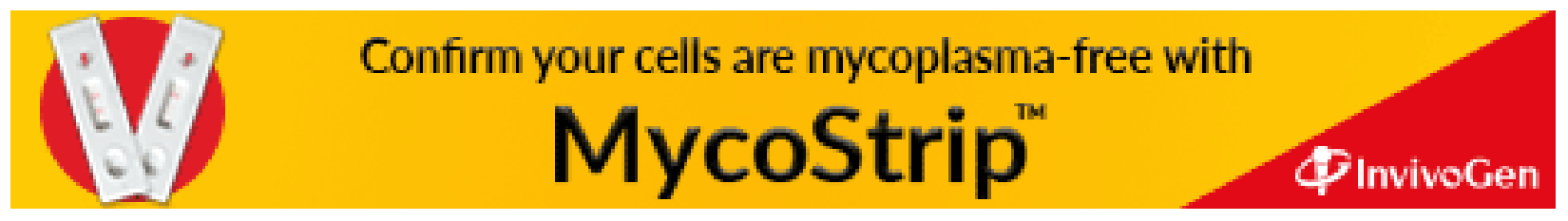

